\title{
Equol in milk of dairy cows is derived from forage legumes such as red clover
}

\author{
Eeva A. Mustonen ${ }^{1} *$, Mikko Tuori ${ }^{2} \dagger$, Ilkka Saastamoinen ${ }^{1}$, Juhani Taponen ${ }^{1}$, Kristiina Wähälä ${ }^{3}$, \\ Hannu Saloniemi ${ }^{1}$ and Aila Vanhatalo ${ }^{2}$ \\ ${ }^{1}$ Department of Production Animal Medicine, University of Helsinki, Helsinki, Finland \\ ${ }^{2}$ Department of Animal Science, University of Helsinki, Helsinki, Finland \\ ${ }^{3}$ Laboratory of Organic Chemistry, Department of Chemistry, University of Helsinki, Helsinki, Finland
}

(Received 27 November 2008 - Revised 18 May 2009 - Accepted 26 May 2009 - First published online 22 July 2009)

The intake of isoflavones and the resulting equol contents of both plasma and milk of the same red clover-fed cows are reported for the first time in cyclic change-over design study. Cows were fed four different red clover silages and two timothy-meadow fescue silages as controls. The red clover silages contained daidzein, formononetin, biochanin A and genistein, whereas the timothy-meadow fescue silages contained no isoflavones. We found a strong association $\left(y=0 \cdot 071 x+2 \cdot 75, R^{2} 0 \cdot 71\right)$ between the formononetin intake $(x)$ and equol concentration $(y)$ in the plasma, while the formononetin intake and milk equol concentration were weakly associated $\left(y=0 \cdot 0035 x+0 \cdot 358, R^{2} 0 \cdot 20\right)$. This means that a small part of the total formononetin in the silage is secreted into milk as equol. The mean equol contents in plasma and milk of cows fed red clover silage diets were in the range of $4.6-8.4 \mathrm{mg} / \mathrm{l}$ and $458-643 \mu \mathrm{g} / \mathrm{l}$, respectively, while the respective values for the control diets were in the range of $0.8-1.5 \mathrm{mg} / \mathrm{l}$ and $171-287 \mu \mathrm{g} / \mathrm{l}$. We showed that shorter growing periods of red clover resulted in higher silage formononetin contents and plasma and milk equol contents, suggesting that the equol content of milk can be manipulated by varying the harvesting strategy of red clover. We conclude that milk equol is derived from the formononetin of red clover silage and that milk from red clover-fed cows can be considered as a source of equol in human nutrition.

Equol: Formononetin: Bovine milk: Isoflavones: Phyto-oestrogens: Red clover

Legume plants possess polyphenolic components such as isoflavones, which have attracted increasing interest among scientists and consumers because of their reported health benefits $^{(1-3)}$. Many of the claimed health benefits have been associated with the isoflavone metabolite equol ${ }^{(4-6)}$, which is a phenolic compound found in mare's urine in $1932^{(7)}$. It was first believed to be oestrogenically inactive ${ }^{(7)}$, but later it was determined oestrogenically active giving rise to a specific breeding problem in sheep ingesting clover of high formononetin content ${ }^{(8-12)}$.

Special interest in equol in human medicine aroused in 1982, when high levels of equol were found in the urine of human adults consuming soya foods ${ }^{(13)}$. This discovery introduced a new aspect of the mechanism of action and effectiveness of soya to the studies of hormone-dependent diseases $^{(4,5)}$. Equol possesses a high affinity for oestrogen receptor $\beta$ and low affinity for oestrogen receptor $\alpha$, and may thus be classified as a natural selective oestrogen receptor modulator ${ }^{(14)}$. The possible role of equol in replacing the effects of oestrogen on the bone, brain and cardiovascular and immune systems is currently under intensive investigation in human medicine and nutrition.

The human intestinal bacteria can produce equol from soya food abundant in daidzein. However, only $20-35 \%$ of the adult human population is believed able to produce equol $^{(4,15,16)}$, whereas animal populations commonly produce equol after ingesting isoflavones ${ }^{(17)}$. The isoflavones daidzein, genistein, biochanin $\mathrm{A}$ and formononetin are typically found in legume feeds, such as red clover (Trifolium pratense) silage, fed to cattle or sheep. In the rumen, biochanin A and genistein are extensively degraded to para-ethylphenol, whereas formononetin is demethylated to daidzein and reduced further to the isoflavan equol ${ }^{(9,10,18,19)}$.

Cow's milk is presumably the only nutriment that contains appreciable amounts of the isoflavan equol itself. In our recent study, a higher concentration of equol was detected in organically than conventionally produced commercial milk $^{(20)}$, which was attributed to the extensive use of forage legumes practiced on organic rather than conventional farms in Finland. Forage legumes such as red clover contain significant amounts of isoflavonoid phyto-oestrogens, while the grass silage predominantly used in conventional farming does not contain those phyto-oestrogens ${ }^{(21)}$. Although it seems obvious that the red clover forage fed to dairy cows is the origin of the equol in plasma and milk, to our knowledge the equol contents of both plasma and milk have not earlier been analysed simultaneously in the same experiment.

\footnotetext{
Abbreviations: RE, red clover early; RL, red clover late; RRE, regrowth of RE; RRL, regrowth of RL.

* Corresponding author: Eeva A. Mustonen, fax +358 19685 1181, email eeva.a.mustonen@ helsinki.fi

$\dagger$ Present address: MTT Agrifood Research Finland, Hyvinkää, Finland.
} 
The present study was designed to determine whether the formononetin in red clover silage fed to dairy cows is a source of equol in plasma and milk. In addition, the influence of various harvesting strategies of red clover on the equol content of plasma and milk was examined.

\section{Experimental methods}

\section{Experimental design, animals and diets}

A cyclic change-over design experiment ${ }^{(22)}$ with twelve Finnish Ayrshire cows and six dietary treatments was conducted at the Viikki Research Farm of the University of Helsinki in 2005, as described previously ${ }^{(23)}$. In brief, the dietary treatments consisted of six different silages offered ad libitum and supplemented with $9.5 \mathrm{~kg} / \mathrm{d}$ of concentrate, consisting of a mixture of barley-oats (Hordeum vulgareAvena sativa; 1:1) and rapeseed (Brassica napus) expellers (24\%; Mildola Ltd, Kantvik, Finland). The two grass silages were prepared from primary growth of early(June 15) or late- (June 30) cut timothy-meadow fescue (Phleum pratense-Festuca pratensis). The four red clover silages were prepared similarly from primary growth of early- (RE, July 1) or late- (RL, July 14) cut red clover and their regrowths (RRE and RRL, August 24, respectively). Since the regrowths were harvested on the same day, the growth period was shorter for the RRL than the RRE silage. The concentrate mixture was distributed to the cows in six equal doses during the day. In addition, the cows were given mineral supplements daily and they had free access to water. The study consisted of four 21-d experimental periods, with an adaptation period from day 1 to day 13 followed by a sampling period from day 14 to day 21 . All feeds given and the leftovers found were weighed daily. The milk yields were recorded daily. During the last week of each period, milk samples were taken from the four consecutive milkings and pooled to form one sample per cow and period. Samples from the silages were collected daily during the last week of each period and pooled to form one sample per period. On the last day of each period, blood samples were collected twice by vacuum puncture of a jugular vein, before morning feeding and $3 \mathrm{~h}$ thereafter. After immediate centrifugation $(4800 \mathrm{~g}, 10 \mathrm{~min})$, the plasma was harvested, frozen and stored at $-80^{\circ} \mathrm{C}$ until analysis, as were the silage and milk samples. All experimental procedures were approved by the Animal Experimental Committee of the University of Helsinki, Finland, in accordance with the 1985 Use of Vertebrates for Scientific Purpose Act.

\section{Analytical procedures}

High-pressure liquid chromatography was used to analyse various isoflavonoid phyto-oestrogens in the silage, plasma and milk samples. The phyto-oestrogens daidzein, formononetin, biochanin A, genistein and coumestrol were analysed in triplicate from silage samples by a method described by Sarelli et al. ${ }^{(24)}$. The concentrations of formononetin and its metabolites equol and demethylangolensin in the plasma samples were analysed by modification of the method described in Mustonen et al. ${ }^{(21)}$. The instrumentation used was a Liquid Chromatograph 1100 (Degasser, Japan); Binary Pump, FLD (Agilent Technologies, Germany); DAD
(Agilent Technologies); ChemStation data system (Agilent Technologies). Flavone, Sigma F 2003, was used as an internal standard. Calibration curves were established in the concentration range $1.172-75 \mu \mathrm{g} / \mathrm{ml}$ for equol and $0 \cdot 195-12.5 \mu \mathrm{g} / \mathrm{ml}$ for the other compounds with correlation over 0.999 . The limit of detection and the limit of quantitation were determined at signal-to-noise ratios of over 3 and 10 , respectively. The results are presented in Table 1 . The recovery level $(93 \pm 11 \%)$ was calculated with flavone. The plasma concentrations are presented as averages of the two samples collected per cow per period. The concentration of equol in milk samples was analysed using the method of Hoikkala et al. ${ }^{(20)}$.

\section{Calculations and statistical analysis}

The daily intake of isoflavonoid phyto-oestrogens, concentrations of isoflavonoids in the plasma and milk samples as well as their daily secretion into the milk were calculated and subjected to ANOVA, using the mixed procedure of Statistical Analysis System (SAS Institute Inc., Cary, NC, USA $)^{(25)}$. Intake of isoflavonoid phyto-oestrogens and secretion into the milk were based on the mean values from the last $6 \mathrm{~d}$ of the experimental period. The statistical model used included block, period, block $\times$ period interaction and treatment as fixed factors, with the cow within the block as the random factor. The sums of squares of the treatment effects were further divided into the following pre-planned single degree-of-freedom comparisons: (1) effect of cut number of red clover silage diets $(\mathrm{RE}+\mathrm{RL} v$. RRE + RRL); (2) effect of growth stage of red clover silage diets (RE + RRL v. RL + RRE); (3) interaction between the cut number and growth stage of red clover diets; (4) effect of plant species, i.e. red clover $v$. grass silage diets $(\mathrm{RE}+\mathrm{RL} v$. grass early + grass late); (5) interaction between the plant species and growth stage of the silage diets.

\section{Results}

The isoflavonoid phyto-oestrogen contents of the experimental silages are presented in Table 2 . No isoflavones were detected in the grass silages. The formononetin contents of the red clover silages were highest for the RE and RRL silages, both characterised by short growing times. The silage DM intakes were $14.3,8.3,10.7,9.0,12.8$ and $11.8 \mathrm{~kg} / \mathrm{d}$ (SEM $0.67 \mathrm{~kg} / \mathrm{d}$ ) for the grass early, grass late, RE, RL, RRE and RRL treatments, respectively. The daily milk yields were $28 \cdot 6,25 \cdot 5,28 \cdot 3,28 \cdot 4,29.1$ and $29.7 \mathrm{~kg} / \mathrm{d}$ (SEM 1.05 kg/d) for the respective treatments ${ }^{(23)}$.

Table 1. The limit of detection (LOD) and the limit of quantitation (LOQ) for the analysed compounds

\begin{tabular}{lcc}
\hline & LOD $(\mu \mathrm{g} / \mathrm{l})$ & LOQ $(\mu \mathrm{g} / \mathrm{l})$ \\
\hline Daidzein 465 emission $\mathrm{nm}$ & 9.9 & 19.8 \\
Genistein $262 \mathrm{~nm}$ & 39.5 & 79.0 \\
Equol 310 emission nm & 58.6 & 117.2 \\
O-DMA 281 nm & 47.9 & 109.6 \\
Formononetin 465 emission nm & 9.9 & 19.8 \\
Biochanin-A 262 nm & 39.5 & 79.0 \\
\hline
\end{tabular}

O-DMA, demethylangolensin. 
Table 2. Isoflavone content in the experimental silages, $\mathrm{g} / \mathrm{kg} \mathrm{DM}$

(Mean values and their standard deviations)

\begin{tabular}{|c|c|c|c|c|c|c|c|c|c|c|}
\hline \multirow{4}{*}{$\begin{array}{l}\text { Plant species } \\
\text { Harvest } \\
\text { Silage diet }\end{array}$} & \multirow{2}{*}{\multicolumn{2}{|c|}{$\frac{\text { Grass }}{\text { Primary growth }}$}} & \multicolumn{8}{|c|}{ Red clover } \\
\hline & & & \multicolumn{4}{|c|}{ Primary growth } & \multicolumn{4}{|c|}{ Regrowth } \\
\hline & \multirow{2}{*}{$\frac{\mathrm{GE}}{\text { Mean }}$} & \multirow{2}{*}{$\frac{\mathrm{GL}}{\text { Mean }}$} & \multicolumn{2}{|c|}{ RE } & \multicolumn{2}{|c|}{$\mathrm{RL}$} & \multicolumn{2}{|c|}{ RRL } & \multicolumn{2}{|c|}{ RRE } \\
\hline & & & Mean & SD & Mean & SD & Mean & SD & Mean & SD \\
\hline Daidzein & 0.00 & 0.00 & $0 \cdot 16$ & 0.014 & 0.29 & 0.033 & 0.16 & 0.017 & 0.17 & 0.008 \\
\hline Formononetin & 0.00 & 0.00 & $5 \cdot 15$ & 0.298 & 2.95 & 0.549 & $6 \cdot 47$ & 0.499 & $4 \cdot 31$ & 0.181 \\
\hline Genistein & 0.00 & 0.00 & 0.73 & 0.033 & 0.65 & 0.052 & 0.50 & 0.069 & 0.55 & 0.030 \\
\hline Biochanin A & 0.00 & 0.00 & 4.37 & 0.243 & $2 \cdot 52$ & 0.416 & 4.65 & 0.326 & 3.23 & 0.219 \\
\hline Total $^{\star}$ & 0.00 & 0.00 & $10 \cdot 41$ & 0.555 & $6 \cdot 40$ & 0.962 & 11.78 & 0.788 & 8.26 & 0.281 \\
\hline
\end{tabular}

GE, grass early; GL, grass late; RE, red clover early; RL, red clover late; RRL, regrowth of RL; RRE, regrowth of RE.

* No coumestrol was detected in the silage samples.

The intake of isoflavones as well as isoflavonoids found in the plasma and milk of the grass- or red clover silage-fed cows is presented in Table 3. The equol contents in plasma and milk were significantly higher $(P<0.001)$ for the red cloverthan for the grass silage-fed cows. Although the intake of formononetin $(x)$ was strongly associated with the equol concentration in plasma $\left(y=0.071 x+2 \cdot 75, R^{2} 0 \cdot 71\right)$, it was weakly associated with the equol concentration in milk $\left(y=0.0035 x+0.358, R^{2} 0.20\right)$. Furthermore, the equol contents of plasma and milk were significantly higher $(P<0.01)$ for the cows fed RRE and RRL than for RE and RL silages. The equol contents in plasma were significantly higher $(P<0.001)$ for cows fed early than late cut red clover silages. No demethylangolensin was found in the milk.

Although grass silage contained no equol precursors, we found some equol in the plasma and milk of grass silage-fed cows. During the four 21-d experimental feeding periods, the cows were situated in adjacent tie-stall cubicles.
The feeding alley was partitioned individually. Despite this, snatching of silage from neighbouring cows did occur. Stealing was totally prevented during the last of the four experimental periods, and no equol was found in plasma and milk of the grass silage-fed cows during this period as presented in the Table 3 .

\section{Discussion}

In the present experimental study, the equol concentration both in plasma and milk of dairy cows fed silage of known isoflavonoid content was investigated. Formononetin in the red clover silage was shown to be the source of equol in plasma and milk of dairy cows. Daidzein as a precursor of equol can contribute to the equol concentration as well. The daidzein content in silage was, however, very low and therefore its contribution to equol concentration is of minor importance in the present study. The milk equol, thus

Table 3. Isoflavonoids in the plasma and milk of grass or red clover silage fed cows

\begin{tabular}{|c|c|c|c|c|c|c|c|c|c|c|c|c|}
\hline \multirow{3}{*}{$\begin{array}{l}\text { Plant species } \\
\text { Harvest } \\
\text { Silage diet }\end{array}$} & \multirow{2}{*}{\multicolumn{2}{|c|}{$\frac{\text { Grass }}{\text { Primary growth }}$}} & \multicolumn{4}{|c|}{ Red clover } & \multirow[b]{3}{*}{ SEM } & \multirow{2}{*}{\multicolumn{5}{|c|}{ Statistical significances* }} \\
\hline & & & \multicolumn{2}{|c|}{ Primary growth } & \multicolumn{2}{|c|}{ Regrowth } & & & & & & \\
\hline & GE & $\mathrm{GL}$ & RE & $\mathrm{RL}$ & RRL & RRE & & $\mathrm{C} 1$ & $\mathrm{C} 2$ & $\mathrm{C} 3$ & $\mathrm{C} 4$ & C5 \\
\hline \multicolumn{13}{|c|}{ Intake of isoflavonoid phyto-oestrogens ( $\mathrm{g} / \mathrm{d})$} \\
\hline Daidzein & 0.0 & 0.0 & 1.66 & 2.59 & 1.83 & $2 \cdot 20$ & 0.12 & 0.34 & $<0.001$ & 0.02 & $<0.001$ & $<0.001$ \\
\hline Formononetin & 0.0 & 0.0 & 53.5 & $26 \cdot 8$ & $75 \cdot 6$ & $55 \cdot 7$ & 2.58 & $<0.001$ & $<0.001$ & 0.18 & $<0.001$ & $<0.001$ \\
\hline Total† & 0.0 & 0.0 & $108 \cdot 3$ & $58 \cdot 1$ & $138 \cdot 0$ & $106 \cdot 6$ & $5 \cdot 29$ & $<0.001$ & $<0.001$ & $<0.001$ & $<0.001$ & $<0.001$ \\
\hline \multicolumn{13}{|c|}{ Concentration in plasma $(\mathrm{mg} / \mathrm{l})$} \\
\hline Equol & 0.84 & 1.50 & $6 \cdot 13$ & 4.58 & 8.39 & 6.93 & 0.362 & $<0.001$ & $<0.001$ & 0.90 & $<0.001$ & 0.22 \\
\hline Equol ${ }^{4 \text { th period }}$ & $0 \ddagger$ & $0 \ddagger$ & $5 \cdot 20$ & 4.54 & 8.91 & 6.95 & & & & & & \\
\hline O-DMA & 0.02 & 0.02 & 0.37 & 0.16 & 0.32 & 0.23 & 0.033 & 0.64 & $<0.001$ & 0.08 & $<0.001$ & 0.002 \\
\hline Formononetin & 0.00 & 0.002 & 0.024 & 0.004 & 0.035 & 0.023 & 0.005 & 0.004 & 0.002 & 0.39 & 0.009 & 0.07 \\
\hline Total & 0.86 & 1.52 & 6.53 & 4.74 & 8.76 & $7 \cdot 18$ & 0.363 & $<0.001$ & $<0.001$ & 0.77 & $<0.001$ & $0 \cdot 12$ \\
\hline \multicolumn{13}{|c|}{ Concentration in milk $(\mu \mathrm{g} / \mathrm{l})$} \\
\hline Equol & 171 & 287 & 488 & 458 & 643 & 583 & $52 \cdot 0$ & 0.001 & 0.37 & 0.76 & $<0.001$ & 0.39 \\
\hline Equol ${ }^{\text {th period }}$ & $0 \ddagger$ & $0 \ddagger$ & 506 & 410 & 695 & 523 & & & & & & \\
\hline \multicolumn{13}{|c|}{ Secretion into milk (mg/d) } \\
\hline Equol & 4.4 & $7 \cdot 4$ & $13 \cdot 4$ & $12 \cdot 2$ & $19 \cdot 1$ & $15 \cdot 9$ & 1.69 & 0.003 & 0.14 & 0.51 & $<0.001$ & 0.56 \\
\hline
\end{tabular}

GE, grass early; GL, grass late; RE, red clover early; RL, red clover late; RRL, regrowth of RL; RRE, regrowth of RE; $O$-DMA, demethylangolensin.

${ }^{*}$ Contrasts: C1, Cut number of red clover; C2, Growth stage of red clover; C3, C1 $\times$ C2 interaction; C4, Plant species i.e. red clover v. grass; C5, Plant species $\times$ growth stage interaction.

$\dagger$ Genistein and biochanin A are included in total intake of phytoestrogens.

$\ddagger$ Possibility for stealing of red clover silage was totally prevented during the fourth experimental period. 
originating from cattle feedstuffs, may contribute to human equol supply. It has been estimated that only one-third of the human population can produce equol from dietary isoflavones $^{(4,15,16)}$. Setchell et al. ${ }^{(5)}$ suggested that the ability to biotransform soya isoflavones to the more potent oestrogenic equol is behind the clinical effectiveness of soya protein in cardiovascular, bone and menopausal health. Furthermore, they presented a classification of human subjects as nonequol producers and equol producers according to the level of plasma equol concentrations $<10$ and $>20 \mu \mathrm{g} / \mathrm{l}$, respectively ${ }^{(5)}$. Equol is predominantly a product of intestinal bacterial metabolism and can presumably not be found as such in any food other than milk. We suggest that cow's milk, with its unique nutrient content, fortified with up to $600 \mu \mathrm{g} / \mathrm{l}$ equol could be an interesting research theme for nutritionists.

In the present study, the average daily formononetin intake $(26-75 \mathrm{~g})$ of the red clover-fed cows was considerably high, as was the plasma equol concentration, $(4.6-8.4 \mathrm{mg} / \mathrm{l})$. The average equol content in milk varied between 458 and $643 \mu \mathrm{g} / \mathrm{l}$. The association between plasma equol concentration and the formononetin fed to dairy cows was strong. In contrast, this strong association was not shown with intake of formononetin and equol concentration in milk, suggesting that relatively small amounts of formononetin were secreted into milk as equol. In addition, it may be that the transfer rate of isoflavonoids from feed to milk is higher at low intake than at higher intake ${ }^{(26)}$. This could explain the reasonable amounts of equol found in the milk of grass silage-fed cows, which were able to snatch small amounts of red clover. In any case, considerable amounts of plasma equol are excreted in urine or faeces.

In the present experiment, the red clover-fed cows produced milk with equol concentrations of $458-643 \mu \mathrm{g} / \mathrm{l}$. When King et al. obtained cow's milk samples from different farms in Australia, the mean equol concentration ranged from 45 to $293 \mu \mathrm{g} / \mathrm{l}$. The highest equol values were found in Western Australian samples collected during spring, when the isoflavonoid-containing clover was the most dominant in pasture ${ }^{(27)}$. Steinshamn et al. ${ }^{(26)}$ fed clover silage to dairy cows without and with concentrate supplementation. With red clover feeding, daily formononetin intake ranged from 47.0 to $33.7 \mathrm{~g} / \mathrm{d}$ and milk equol content 364 and $273 \mu \mathrm{g} / \mathrm{l}$, respectively.

Antignac et al. ${ }^{(28,29)}$ investigated the occurrence of phytooestrogens in commercial milk samples and found equol in all analysed samples at relatively high concentrations of $14-293 \mu \mathrm{g} / \mathrm{l}$. They investigated whether the type of milk sample (conventional $v$. organic agriculture) affected the phyto-oestrogen content in milk. Organic milk samples contained equol averaging $191 \mu \mathrm{g} / \mathrm{l}$, whereas conventional milk samples averaged only $36 \mu \mathrm{g} / \mathrm{l}^{(29)}$. In our earlier study, it was shown that Finnish commercial organic skimmed milk contained equol averaging $411 \mu \mathrm{g} / \mathrm{l}$, whereas conventionally produced milk averaged $62 \mu \mathrm{g} / \mathrm{l}^{(20)}$. Purup et al. ${ }^{(30)}$ presented similar figures from Danish bulk milk samples (230 and $41 \mu \mathrm{g} / \mathrm{l}$, respectively).

The equol in milk is clearly derived from the formononetin of red clover silage. Timothy-meadow fescue silages used as controls did not contain isoflavonoids. A strong association between the intake of formononetin and equol concentration in plasma was shown. Furthermore, the results suggest that by altering the harvesting strategy, red clover silages can be manipulated to contain more formononetin, i.e. by varying the harvesting time, the formononetin content of silage was more than doubled from 3 to $6.5 \mathrm{~g} / \mathrm{kg}$ in DM. When regrowth of red clover had the shortest growing period, the silage formononetin content was at the highest $(6 \cdot 5 \mathrm{~g} / \mathrm{kg}$ in DM). Consequently, the total daily intake of formononetin and the plasma and milk equol concentrations were maximal, $76 \mathrm{~g} / \mathrm{d}$, 8.4 and $643 \mu \mathrm{g} / \mathrm{l}$, respectively. The equol concentrations in plasma are well in line with earlier studies. Braden et al. ${ }^{(31)}$ fed freshly cut red clover forage to heifers and found plasma equol levels between 1 and $6 \mathrm{mg} / \mathrm{l}$. In the studies of Lundh et al. ${ }^{(32)}$, the plasma concentration of equol was determined in blood samples from dairy cattle. When the daily intake of formononetin was $13-14 \mathrm{~g}$, the equol level was $2 \mathrm{mg} / \mathrm{l}$. In an earlier study with intake of $3.5 \mathrm{~g}$ formononetin, the maximum equol level of $0.27 \mathrm{mg} / \mathrm{l}$ was detected $3 \mathrm{~h}$ after ingestion $^{(33)}$. In both studies, red clover was used as a source of isoflavones.

These results and earlier observations demonstrate that animal feeding does explain the differences in the isoflavonoid phyto-oestrogen contents in milk, the red clover forage being the main source of equol. Due to its nitrogen-fixing ability, red clover is widely used in organic agriculture, which illustrates why the phyto-oestrogen concentrations in the organic milk samples are higher than in conventionally produced milk. These results show that red clover-fed cows produce more equol in their milk, which may spark further interest in organically produced milk or milk specially produced for high equol concentration. The possible health benefits or risks associated with elevated milk equol concentration should be evaluated thoroughly as equol is classified as a natural selective oestrogen receptor modulator. Red clover-fed cows have high equol concentrations in their plasma and could be interesting material for human health-associated studies as well as studies directed to investigate cattle health.

\section{Conclusions}

This is the first study of the intake of isoflavonoids and the simultaneous measurements of equol contents of both plasma and milk of red clover silage-fed dairy cows. We showed a strong association between formononetin intake and equol concentration in plasma. The equol content in cow's milk can be as high as $600-700 \mu \mathrm{g} / \mathrm{l}$ with red clover silage feeding, even though it is clear that only a small part of the formononetin is secreted into milk as equol. The equol content in milk can be manipulated by varying the harvesting strategy of red clover. Shorter growing periods of red clover resulted in higher formononetin contents in the silage and equol content in the plasma and milk. Milk equol is derived from the formononetin of red clover silage and red clover-fed cows' milk can be considered as a source of equol in human nutrition.

\section{Acknowledgements}

The present study was supported by the grants from Mercedes Zachariassen Foundation (4700752, 4700754), Finland. Also Ministry of Agriculture and Forestry and National Emergency 
Supply Agency in Finland contributed to the funding of the animal study. E. M., M. T., J. T., A. V. and H. S. were responsible for the experimental design of the study and the execution of the study. I. S., K. W. and H. S. were responsible for the analytical work on phyto-oestrogens. M. T. and A. V. were responsible for the statistical analysis. All authors were involved in the data interpretation and preparation of the manuscript. None of the authors had any personal or financial conflict of interest.

\section{References}

1. Xiao CW (2008) Health effects of soy protein and isoflavones in humans. $J$ Nutr 138, 1244S-1249S.

2. Ma D-F, Qin L-Q, Wang P-Y, et al. (2008) Soy isoflavone intake increases bone mineral density in the spine of menopausal women: meta-analysis of randomized controlled trials. Clin Nutr 27, 57-64.

3. Taku K, Umegaki K, Sato Y, et al. (2007) Soy Isoflavones lower serum total and LDL cholesterol in humans: a metaanalysid of 11 randomized controlled trials. Am J Clin Nutr 85, $1148-1156$.

4. Setchell K, Borriello S, Hulme P, et al. (1984) Nonsteroidal estrogens of dietary origin: possible roles in hormone-dependent disease. Am J Clin Nutr 40, 569-578.

5. Setchell KDR, Brown NM \& Lydeking-Olsen E (2002) The clinical importance of the metabolite equol - a clue to the effectiveness of soy and its isoflavones. J Nutr 132, 3577-3584.

6. Yuan J-P, Wang J-H \& Liu X (2007) Metabolism of dietary soy isoflanoves to equol by human intestinal microflora implications for health. Mol Nutr Food Res 51, 765-781.

7. Marrian GF \& Haslewood GAD (1932) Equol, a new inactive phenol isolated from the ketohydroxyoestrin fraction of mares' urine. Biochem J 26, 1227-1232.

8. Millington AJ, Francis CM \& McKeown NR (1964) Wether bioassay of animal pasture legumes. II. The oestrogenic activity of nine strains of Trifolium subterraneum L. Aust J Agric Res 15, 527-536.

9. Batterham TJ, Hart NK, Lamberton AJ, et al. (1965) Metabolism of oestrogenic isoflavones in sheep. Nature 206, 509.

10. Shutt DA \& Braden AWH (1968) The significance of equol in relation to the oestrogenic responses in sheep ingesting clover with a high formononetin content. Aust J Agric Res 19, $545-553$

11. Shutt DA \& Cox RI (1972) Steroid and phyto-oestrogen binding to sheep uterine receptors in vitro. J Endocrinol 52, 299-310.

12. Bennetts HW, Uuderwood EJ \& Shier FL (1946) A specific breeding problem of sheep on subterranean clover pastures in Western Australia. Aust Vet J 22, 2-12.

13. Axelson M, Kirk DN, Farrant RD, et al. (1982) The identification of the weak oestrogen equol [7-hydroxy3-(4'-hydroxyphenyl)chroman] in human urine. Biochem $J$ 201, $353-357$.

14. Setchell KDR, Clerici C, Lephart ED, et al. (2005) S-equol, a potent ligand for estrogen receptor $\beta$, is the exclusive enantiomeric form of the soy isoflavone metabolite produced by human intestinal bacterial flora. Am J Clin Nutr 81, 1072-1079.

15. Lampe J, Karr S, Hutchins A, et al. (1998) Urinary equol excretion with a soy challenge: Influence of habitual diet. Proc Soc Exp Biol Med 217, 335-339.
16. Rowland IR, Wiseman H, Sanders TA, et al. (2000) Interindividual variation in metabolism of soy isoflavones and lignans: influence of habitual diet on equol production by the gut microflora. Nutr Cancer 36, 27-32.

17. Lundh T (1995) Metabolism of estrogenic isoflavones in domestic animals. Proc Soc Exp Biol Med 208, 33-39.

18. Nilsson A, Hill JL \& Davies HL (1967) An in vitro study of formononetin and biochanin A metabolism in rumen fluid from sheep. Biochim Biophys Acta 148, 92-98.

19. Dickinson JM, Smith GR, Randel RD, et al. (1988) In vitro metabolism of formononetin and biochanin a in bovine rumen fluid. J Anim Sci 66, 1969-1973.

20. Hoikkala A, Mustonen E, Saastamoinen I, et al. (2007) High levels of equol in organic skimmed Finnish cow milk. Mol Nutr Food Res 51, 782-786.

21. Mustonen E, Jokela T, Saastamoinen I, et al. (2006) High serum S-equol content in red clover fed ewes: The classical endocrine disruptor is a single enantiomer. Environ Chem Lett 3, 154-159.

22. Davis AW \& Hall WB (1969) Cyclic change-over designs. Biometrika 56, 283-293.

23. Vanhatalo A, Pursiainen P, Kuoppala K, et al. (2008) Effects of harvest time of red clover silage on milk production and composition. In Biodiversity and Animal Feed Future Challenges for Grassland Production. Grassland Science in Europe, vol. 13, pp. 391-393 [A Hopkins, J Gustafsson, J Bertilsson, G Dahlin, N Nilsdotter-Linde and E Spörndly, editors]. Uppsala: SLU Repro.

24. Sarelli L, Tuori M, Saastamoinen I, et al. (2003) Phytoestrogen content of birdsfoot trefoil and red clover: effects of growth stage and ensiling method. Acta Agric Scand Anim Sci 53, $58-63$.

25. Littell RC, Henry PR \& Ammerman CB (1998) Statistical analysis of repeated measures data using SAS procedures. J Anim Sci 76, 1216-1231.

26. Steinshamn H, Purup S, Thuen E, et al. (2008) Effects of clovergrass silages and concentrate supplementation on the content of phytoestrogens in dairy cow milk. J Dairy Sci 91, 2715-2725.

27. King RA, Mano MM \& Head RJ (1998) Assessment of isoflavonoid concentrations in Australian bovine milk samples. $J$ Dairy Res 65, 479-489.

28. Antignac JP, Cariou R, Le Bizec B, et al. (2003) Identification of phytoestrogens in bovine milk using liquid chromatography/ electrospray tandem mass spectrometry. Rapid Commun Mass Spectrom 17, 1256-1264.

29. Antignac J, Cariou R, Bizec BL, et al. (2004) New data regarding phytoestrogens content in bovine milk. Food Chem 87, 75-81.

30. Purup S, Hansen-Møller J, Sejrsen K, et al. (2005) Increased phytoestrogen content in organic milk and the biological importance. DARCOFenews. http://www.darcof.dk/enews/ jun05/milk.html

31. Braden AWH, Thain RI \& Shutt DA (1971) Comparison of plasma phyto-oestrogen levels in sheep and cattle after feeding on fresh clover. Aust J Agric Res 22, 663-670.

32. Lundh TJ, Pettersson HI \& Martinsson KA (1990) Comparative levels of free and conjugated plant estrogens in blood plasma of sheep and cattle fed estrogenic silage. J Agric Food Chem 38, $1530-1534$.

33. Lundh TJ, Pettersson HI \& Kiessling K-H (1988) Liquid chromatographic determination of the estrogens daidezein, formononetin, coumestrol, and equol in bovine blood plasma and urine. J Assoc Off Anal Chem 71, 938-941. 